\title{
POU2F1 Gene
}

National Cancer Institute

\section{Source}

National Cancer Institute. POU2F1 Gene. NCI Thesaurus. Code C28649.

This gene plays a role in transcriptional activation and modulates immunoglobulin activity. 